\title{
A novel ribonuclease with antiproliferative activity toward leukemia and lymphoma cells and HIV-1 reverse transcriptase inhibitory activity from the mushroom, Hohenbuehelia serotina
}

\author{
RUI ZHANG ${ }^{1}$, LIYAN ZHAO ${ }^{2}$, HEXIANG WANG ${ }^{1}$ and TZI BUN NG ${ }^{3}$ \\ ${ }^{1}$ State Key Laboratory for Agrobiotechnology and Department of Microbiology, China Agricultural University, \\ Beijing 100193; ${ }^{2}$ College of Food Science and Technology, Nanjing Agricultural University, Weigang, Nanjing 210095; \\ ${ }^{3}$ School of Biomedical Sciences, Faculty of Medicine, The Chinese University of Hong Kong, \\ Shatin, New Territories, Hong Kong, SAR, P.R. China
}

Received August 5, 2013; Accepted October 30, 2013

DOI: $10.3892 / \mathrm{ijmm} .2013 .1553$

\begin{abstract}
In this study, a 27-kDa ribonuclease (RNase) was purified from the dried fruiting bodies of the mushroom, Hohenbuehelia serotina. The isolation protocol involved anion exchange chromatography, affinity chromatography, cation exchange chromatography and gel filtration in succession. The RNase was unadsorbed on DEAE-cellulose, but was adsorbed on Affi-gel blue gel and CM-cellulose. The N-terminal amino acid sequence was TVGGSLAEKGN which showed homology to other fungal RNases to a certain degree. The RNase exhibited maximal RNase activity at $\mathrm{pH} 5$ and $80^{\circ} \mathrm{C}$. It demonstrated the highest ribonucleolytic activity toward poly $(\mathrm{C})$, a relatively high activity toward poly(U), and a considerably weaker activity toward poly(A) and (G). The RNase inhibited human immunodeficiency virus type 1 (HIV-1) reverse transcriptase with an $\mathrm{IC}_{50}$ of $50 \mu \mathrm{M}$ and reduced $\left[{ }^{3} \mathrm{H}\right.$-methyl]-thymidine uptake by L1210 leukemia cells and MBL2 lymphoma cells with an $\mathrm{IC}_{50}$ of $25 \mu \mathrm{M}$ and $40 \mu \mathrm{M}$, respectively.
\end{abstract}

\section{Introduction}

The literature pertaining to the Hohenbuehelia species is limited and confined to the following reports. Vafina and Molodtsov described the synthesis of some p-nitrophenyl

Correspondence to: Professor Hexiang Wang, State Key Laboratory for Agrobiotechnology and Department of Microbiology, China Agricultural University, No. 2 Summer Palace Road West, Haidian, Beijing 100193, P.R. China

Email: hxwang@cau.edu.cn

Professor Tzi Bun Ng, School of Biomedical Sciences, Faculty of Medicine, The Chinese University of Hong Kong, No. 18 Zexiang Street, Shatin, New Territories, Hong Kong, SAR, P.R. China Email: b021770@mailserv.cuhk.edu.hk

Key words: ribonuclease, mushroom, Hohenbuehelia serotina, antiproliferative, purification
2-acylamino-2-deoxy-D-glucosides and their hydrolysis using Hohenbuehelia serotina $\beta$-D-hexosaminidase (1). The culture filtrate of Hohenbuehelia geogenius inhibited the growth of two rapidly growing grafted tumors (Ehrlich ascites carcinoma and L1210 lymphoid leukemia) and a slow-growing spontaneous mammary tumor in mice. An active substance was isolated by solid-liquid extraction and column chromatography and its chemical structure was elucidated (2).

Anti-A agglutinins, the reaction of which has been shown to be strongly inhibited by $\mathrm{N}$-acetyl-D-galactosamine, have been detected in Hohenbuehelia serotina extracts (3). Two strains of Hohenbuehelia atrocaerulea (Pleurotaceae) that produce pleurotin, a naphthoquinone antibiotic originally obtained from Pleurotus griseus, have been identified. Solid substrate fermentation for two months yielded $1-2 \mathrm{mg} / \mathrm{l}$ of pleurotin. Shipley et al (4) detailed the developmental process, which depended on inclusion in the medium of an aqueous extract of alder woodm leading to a yield of pleurotin exceeding $300 \mathrm{mg} / \mathrm{l}$ from liquid fermentation. Bala et al reported that water, ethanol and hexane extracts of the Hohenbuehelia species inhibited growth of Gram-positive Staphylococcus aureus and Gram-negative Escherichia coli (5). Bala et al (6) further demonstrated that a water extract of Hohenbuehelia species inhibited six pathogens each comprising of two Grampositive and -negative bacteria together with two fungi.

Polysaccharides extracted from the fruiting bodies of Hohenbuehelia serotina have exhibited antitumor activity in sarcoma 180-bearing mice (7). The molecular weights of these polysaccharides ranged from $1.19 \times 103$ to $1.55 \times 104 \mathrm{Da}$ and composed of ribose, arabinose, mannose, glucose and galactose at a ratio of 0.65:0.69:9.35:14.24:5.47; they were isolated by $\mathrm{Li}$ et al (8). However, there is a dearth of information on the proteinaceous constituents of the Hohenbuehelia species.

Ribonucleases (RNases) have been isolated and characterized from a multitude of organisms, including parasites, bacteria, fungi, plants and a variety of tissues from mammals (9-17) RNases display different activities, such as antitumor (18-25), immunosuppressive (26), antifungal (27), and antiviral $(28,29)$ activities. Due to the array of potentially exploitable activities, RNases have drawn the attention of many researchers. 
RNases have been purified from the fruiting bodies or mycelia of a diversity of mushroom species. These mushrooms include some common edible and medicinal species as follows: Pleurotus ostreatus (30,31), Irpex lacteus (32), Volvariella volvacea (33), Pleurotus tuber-regium (34), Pleurotus pulmonarius (35), Agrocybe cylindracea (36), Russula virescens (37), Termitomyces globules (38), Cantharellus cibarius (39), Pleurotus sajor-caju (40), Ganoderma lucidum (41), Clitocybe maxima (42), Thelephora ganbajun (43), Boletus griseus (44), Hypsizigus marmoreus (45), Russula delica $(16,46)$ and Lyophyllum shimeiji (47). The aim of this study was to isolate and characterize an RNase isolated from the dried fruiting bodies of the edible fungus, Hohenbuehelia serotina, and to compare its characteristics and N-terminal sequence with those of RNases isolated from the aforementioned species. The comparison would reveal any differences between RNases from different species and our findings may expand the knowledge and provide further information on this fungus.

\section{Materials and methods}

Isolation of RNase from Hohenbuehelia serotina. The dried fruiting bodies (200 g) of the edible mushroom, Hohenbuehelia serotina, obtained from North China were extracted with distilled water $(2 \mathrm{ml} / \mathrm{g}$ ) using a Waring blender (Waring Laboratory Supplies, Torrington, CT, USA). Tris- $\mathrm{HCl}$ buffer ( $\mathrm{pH} 7.2,1 \mathrm{M}$ ) was added to the supernatant, obtained by centrifugation of the homogenate, until the concentration of Tris reached $10 \mathrm{mM}$. The supernatant was subjected to ion exchange chromatography on a $5 \times 15 \mathrm{~cm}$ column of DEAEcellulose (Sigma, St. Louis, MO, USA) in $10 \mathrm{mM}$ Tris- $\mathrm{HCl}$ buffer ( $\mathrm{pH}$ 7.2). Following elution of the unadsorbed proteins (fraction D1) with the same buffer, the adsorbed proteins were desorbed sequentially with $0.2 \mathrm{M} \mathrm{NaCl}$ and $1 \mathrm{M} \mathrm{NaCl}$ in Tris- $\mathrm{HCl}$ buffer to form fractions D2 and D3, respectively. Fraction D1 was then directly chromatographed on a $5 \times 15 \mathrm{~cm}$ Affi-gel blue gel column (Bio-Rad, Hercules, CA, USA) in $10 \mathrm{mM}$ Tris- $\mathrm{HCl}$ buffer ( $\mathrm{pH}$ 7.2). The unadsorbed proteins were eluted as fraction B1. The adsorbed proteins were eluted sequentially with $0.2 \mathrm{M} \mathrm{NaCl}$ and $1 \mathrm{M} \mathrm{NaCl}$ in Tris-HCl buffer and collected as fractions B2 and B3, respectively. Fraction B2 was dialyzed against $10 \mathrm{mM} \mathrm{NH} \mathrm{H}_{4} \mathrm{OAc}$ buffer ( $\mathrm{pH}$ 5) subjected to ion exchange chromatography on a $2.5 \times 20 \mathrm{~cm} \mathrm{CM}$-cellulose (Sigma) column in $10 \mathrm{mM} \mathrm{NH} \mathrm{NHAc}_{4} \mathrm{Ouffer}$ (pH 5). Following the removal of the unadsorbed proteins (fraction CM1), the adsorbed proteins were eluted with $10 \mathrm{mM} \mathrm{NH}_{4} \mathrm{OAc}$ buffer ( $\mathrm{pH}$ 5) containing a linear gradient of 0-1 $\mathrm{M} \mathrm{NaCl}$, and collected as fractions CM2 and CM3. Fraction CM3 was dialyzed, lyophilized and further purified on a Superdex $75 \mathrm{HR}$ 10/30 column in $0.2 \mathrm{M} \mathrm{NH}_{4} \mathrm{HCO}_{3}$ buffer ( $\mathrm{pH} 8.5$ ) using an AKTA Purifier (GE Healthcare, Piscataway, NJ, USA).

Molecular mass determination by sodium dodecyl sulfatepolyacrylamide gel electrophoresis (SDS-PAGE) and by fast protein liquid chromatography (FPLC)-gel filtration. SDS-PAGE was conducted following the protocol of Laemmli and Favre (48), using a $12 \%$ resolving gel and a 5\% stacking gel. At the conclusion of electrophoresis, staining of the gel with Coomassie brilliant blue was carried out. FPLC-gel filtration was performed using a Superdex 75 HR 10/30 column that had been calibrated with molecular mass standards using an AKTA Purifier (GE Healthcare).

Analysis of $N$-terminal amino acid sequence. The amino-acid sequence of the purified protein was determined by means of automated Edman degradation. The amino acid sequence was determined using an HP G1000A Edman degradation unit and an HP 1000 HPLC system (Agilent Technologies, Santa Clara, CA, USA).

Assay for RNase activity. The activity of the purified RNase toward yeast tRNA (Sigma) was assayed by determining the generation of acid-soluble UV-absorbing species (reaction products) with the method of Wang and $\mathrm{Ng}$ (52). The RNase was incubated with $200 \mu \mathrm{g}$ tRNA in $150 \mu \mathrm{g}$ of $100 \mathrm{mM}$ MES buffer ( $\mathrm{pH} 6.0$ ) at $37^{\circ} \mathrm{C}$ for $1 \mathrm{~h}$. The reaction was terminated by the addition of $350 \mu \mathrm{l}$ of ice-cold $3.4 \%$ perchloric acid. After remaining on ice for $15 \mathrm{~min}$, the sample was centrifuged $(15,000 \times \mathrm{g})$ at $4^{\circ} \mathrm{C}$ for $15 \mathrm{~min}$. The $\mathrm{OD}_{260}$ of the supernatant was read after appropriate dilution. One unit of enzymatic activity is defined as the amount of enzyme that induces an increase in $\mathrm{OD}_{260}$ of one per minute in the acid-soluble fraction per milliliter of reaction mixture under the specified conditions.

Activity of RNase toward polyhomoribonucleotides. The ribonucleolytic activity of the purified RNase toward various polyhomoribonucleotides as substrates was determined with a modification of a previously described method (33). The incubation of RNase with $100 \mu \mathrm{g}$ poly $(\mathrm{A}), \operatorname{poly}(\mathrm{C})$, $\operatorname{poly}(\mathrm{G})$ or poly(U) was carried out at $37^{\circ} \mathrm{C}$ for $1 \mathrm{~h}$ in $250 \mu \mathrm{l}$ of $100 \mathrm{mM}$ sodium acetate buffer ( $\mathrm{pH} 5.0$ ), prior to the addition of $250 \mu \mathrm{l}$ of ice-cold $1.2 \mathrm{~N}$ perchloric acid containing $20 \mathrm{mM}$ lanthanum nitrate to terminate the reaction. The reaction mixture was left on ice for $15 \mathrm{~min}$ prior to centrifugation at $15,000 \mathrm{x} \mathrm{g}$ for $15 \mathrm{~min}$ at $4^{\circ} \mathrm{C}$. After appropriate dilution, the absorbance of the supernatant was read at $260 \mathrm{~nm}$ [for substrates poly(A), poly $(\mathrm{G})$ and poly $(\mathrm{U})]$ or at $280 \mathrm{~nm}$ [for substrate poly $(\mathrm{C})]$.

Assay for ability to inhibit human immunodeficiency virus type 1 reverse transcriptase $(H I V-1 R T)$. The assay to determine the HIV-1 RT inhibitory activity of Hohenbuehelia serotina RNase was executed using a non-radioactive reverse transcriptase ELISA kit (Sigma-Aldrich, Trading Co., Ltd., Shanghai, China) as previously described (49).

Assay for anti-proliferative activity of RNase isolated from Hohenbuehelia serotina. The anti-proliferative activity of the purified RNase was determined as follows: the L1210 and MBL2 cells were maintained in Dulbecco's modified Eagle's medium (DMEM) supplemented with $10 \%$ fetal bovine serum (FBS) and $100 \mathrm{mg} / \mathrm{l}$ streptomycin and $100 \mathrm{IU} / \mathrm{ml}$ penicillin, at $37^{\circ} \mathrm{C}$ in a humidified atmosphere of $5 \% \mathrm{CO}_{2}$. Cells $\left(1 \times 10^{4}\right)$ in their exponential growth phase were seeded into each well of a 96-well culture plate and incubated for $3 \mathrm{~h}$ prior to the addition of the purified RNase followed by incubation for a further $48 \mathrm{~h}$. The radioactive precursor, $1 \mu \mathrm{Ci}\left[{ }^{3} \mathrm{H}\right.$-methyl]-thymidine, was added to each well followed by incubation for $6 \mathrm{~h}$ before the cultures were harvested by means of a cell harvester. The incorporated radioactivity was determined by liquid scintillation counting, as previously described (40). 
Table I. Yields (from $650 \mathrm{~g}$ fresh Hohenbuehelia serotina fruiting bodies) and RNase activity (determined in $0.1 \mathrm{M}$ MES buffer, $\mathrm{pH} 6.0,37^{\circ} \mathrm{C}$ ) of various chromatographic fractions.

\begin{tabular}{lrccrr}
\hline Fraction & $\begin{array}{c}\text { Yield } \\
(\mathrm{mg})\end{array}$ & $\begin{array}{c}\text { RNase } \\
\text { activity } \\
(\mathrm{U} / \mathrm{mg})\end{array}$ & Fraction & $\begin{array}{r}\text { Yield } \\
(\mathrm{mg})\end{array}$ & $\begin{array}{r}\text { RNase } \\
\text { activity } \\
(\mathrm{U} / \mathrm{mg})\end{array}$ \\
\hline Extract & 2018 & 35.7 & $\mathrm{CM} 1$ & 19.0 & $<1$ \\
D1 & 459 & 98.6 & $\mathrm{CM} 2$ & 13.4 & 51.8 \\
D2 & 403 & 12.5 & $\mathrm{CM} 3$ & 23.5 & 983.0 \\
D3 & 529 & $<1$ & $\mathrm{SU} 1$ & 3.6 & 102.8 \\
B1 & 165 & $<1$ & $\mathrm{SU} 2$ & 6.9 & 2705.3 \\
B2 & 79.3 & 369.5 & SU3 & 5.9 & 86.1 \\
B3 & 81.2 & 15.7 & & & \\
\hline
\end{tabular}

RNase, ribonuclease.

\section{Results}

Isolation of RNase. Ion exchange chromatography of the extract on DEAE-cellulose yielded three fractions D1, D2 and D3 containing similar amounts of proteins. RNase activity was found only in the unadsorbed fraction D1. D1 was separated on Affi-gel blue gel into one unadsorbed and also the largest fraction (B1), together with two adsorbed fractions (B2 and B3). Fraction B2 was the only fraction with strong RNase activity. This fraction was resolved on CM-cellulose into an unadsorbed fraction CM1 devoid of RNase activity, an adsorbed fraction CM2 with weak RNase activity, and the most strongly adsorbed fraction CM3 containing the bulk of RNase activity (Fig. 1). Fraction CM3 was resolved into three fractions, SU1, SU2 and SU3 upon gel filtration on Superdex 75. RNase activity resided in the second fraction SU2 (Fig. 2 and Table I).

Determination of molecular mass. Fraction SU2 appeared as a single band with a molecular mass of $27 \mathrm{kDa}$, as shown by SDS-PAGE (Fig. 3).

Analysis of $\mathrm{N}$-terminal amino acid sequence. The amino acid sequence was abtained by an HP 1000 HPLC system depending on Edman degradation. The $\mathrm{N}$-terminal sequence was as follows: TVGGSLAEKGN, which showed homology to other fungal RNases to a certain degree (Table II).

Determination of optimum $\mathrm{pH}$ and optimum temperature. The optimum pH (Fig. 4) and temperature (Fig. 5) for the purified RNase were $\mathrm{pH} 5.0$ and $80^{\circ} \mathrm{C}$, respectively.

Determination of polyhomoribonucleotide specificity. The RNase exerted a ribonucleolytic activity of 455.1, 311.2, 119.4 and $105 \mathrm{U} / \mathrm{mg}$ toward $\operatorname{poly}(\mathrm{C})$, $\operatorname{poly}(\mathrm{U})$, poly(A) and $\operatorname{poly}(\mathrm{G})$, respectively.

HIV-1 RT inhibitory activity. The RNase inhibited HIV-1 RT with an $\mathrm{IC}_{50}$ of $50 \mu \mathrm{M}$ (Table III).

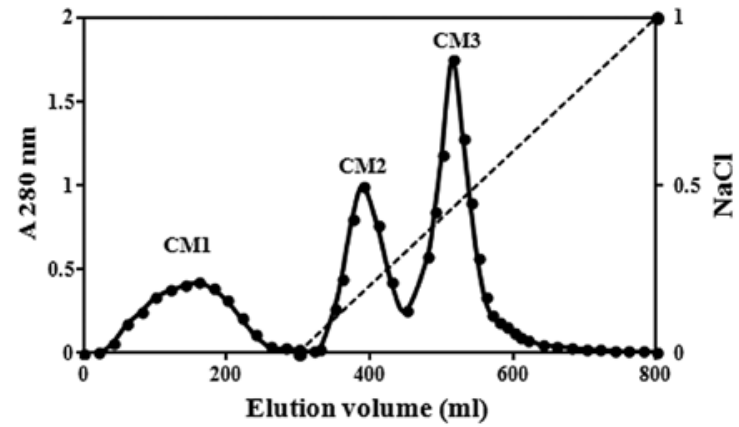

Figure 1. Ion exchange chromatography on CM-Sepharose. Sample: fraction B2 which was previously adsorbed on Affi-gel blue gel. Column dimensions: $2.5 \times 20 \mathrm{~cm}$. Starting buffer: $10 \mathrm{mM} \mathrm{NH}_{4} \mathrm{Ac}$ (pH 5.2). Slanting dotted line across the right side of the chromatogram represents the linear 0-1 $\mathrm{M} \mathrm{NaCl}$ gradient used to elute adsorbed proteins.

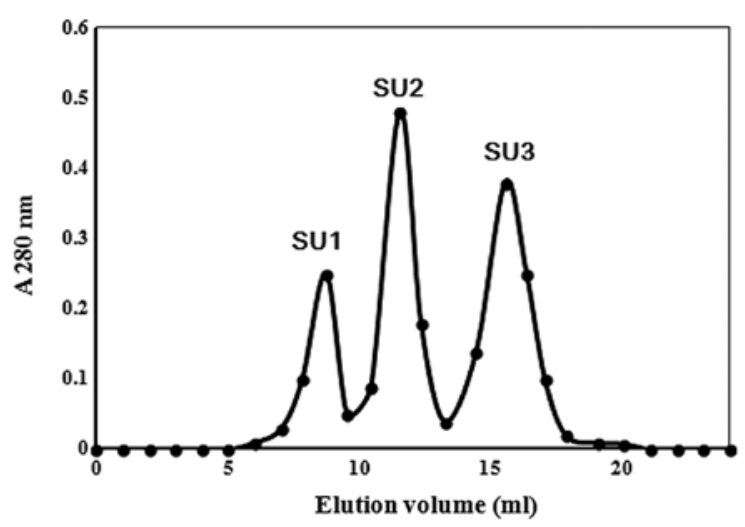

Figure 2. FPLC-gel filtration of fraction CM3 on a Superdex 75 HR10/30 column. Buffer, $0.2 \mathrm{M} \mathrm{NH}_{4} \mathrm{HCO}_{3}(\mathrm{pH} 8.5$ ); flow rate, $0.4 \mathrm{ml} / \mathrm{min}$; fraction size, $0.8 \mathrm{ml}$.

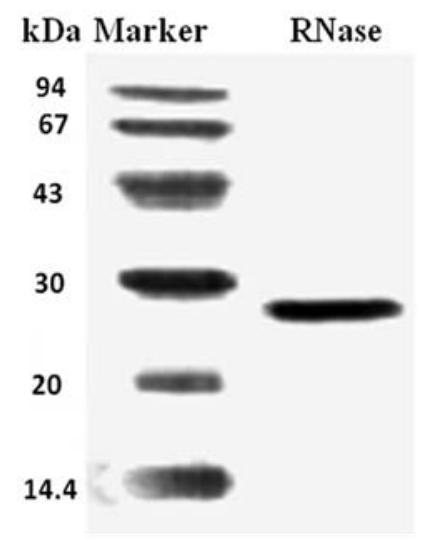

Figure 3. Sodium dodecyl sulfate polyacrylamide gel electrophoresis (SDS-PAGE) of purified Hohenbuehelia serotina ribonuclease (RNase) (fraction SU2). The molecular mass of the marker proteins are, from top to bottom, $94,67,43,30,20$ and $14.4 \mathrm{kDa}$.

Anti-proliferative activity toward tumor cells. The RNase inhibited $\left[{ }^{3} \mathrm{H}\right.$-methyl]-thymidine uptake by $\mathrm{L} 1210$ cells and MBL2 cells with an $\mathrm{IC}_{50}$ of 25 and $40 \mu \mathrm{M}$, respectively (Table III). 
Table II. N-terminal sequence of Hohenbuehelia serotina (HS) ribonuclease (RNase) in comparison with RNases isolated from other mushrooms.

\begin{tabular}{ll}
\hline RNase & \multicolumn{1}{c}{ N-terminal sequence } \\
\hline HS: & TVGGSLAEKGN \\
TG: & DADIAVWAPPVNAQN \\
CM: & ETAHTHAGIQYSTVDVNNSIMKAVGGGAGN \\
PP: & AISANNERKGVNQQSVQNTYQENDV \\
VV: & APYVQLFRPLIQPQVLATFAIANNMAQY \\
LE: & ISSGCGTTGALSCSSNAKGTCCFEAPGGLI \\
IL: & VNSGCGTSGAESCSNSDDGTCCFEAPGGLL \\
DI: & GQPRQPQPQLLV \\
PE: & GEVVQYYP \\
PS: & DNGEAGRAAR \\
GL: & HLPBVPSFAYGSIKVYIN \\
RV: & TDHTLDTMMTHTLRD \\
PO: & ETGVRSCNCAGRSFTGTDVTNAIRSARAGGSGN \\
PT: & ALTAQDNRVRVGNRIVGNNFNFAAVQAAYY
\end{tabular}

TG, Thelephora ganbajun; CM, Clitocybe maxima; PP, Pleurotus pulmonarius; VV, Volvariella volvacea; LE, Lentinus edodes; IL, Irpex lacteus; DI, Dictyophora indusiata; PE, Pleurotus eryngii; PS, Pleurotus sajor-caju; GL, Ganoderma lucidum; RV, Russulus virescens; PO, Pleurotus ostreatus; PT, Pleurotus tuber-regium.

Table III. Inhibition rates (\%) of RNase on growth of MBL2 cells, L1210 cells, and HIV-1 RT.

\begin{tabular}{lccc}
\hline & \multicolumn{3}{c}{ Inhibition rates $(\%)$} \\
\cline { 2 - 4 } Dose $(\mu \mathrm{M})$ & HIV-1 RT & L1210 & MBL2 \\
\hline 10 & $13.5 \pm 0.9$ & $24.6 \pm 1.8$ & $18.7 \pm 1.1$ \\
20 & $21.4 \pm 1.6$ & $40.9 \pm 2.7$ & $31.4 \pm 2.3$ \\
40 & $42.1 \pm 2.7$ & $72.1 \pm 5.2$ & $49.7 \pm 3.8$ \\
80 & $73.4 \pm 4.3$ & $94.3 \pm 5.5$ & $73.6 \pm 5.9$ \\
$\mathrm{IC}_{50}(\mu \mathrm{M})$ & 49.9 & 24.8 & 40.3 \\
\hline
\end{tabular}

RNase, ribonuclease; HIV-1 RT, human immunodeficiency virus type 1 reverse transcriptase.

\section{Discussion}

RNase isolated from Hohenbuehelia serotina is characterized by an N-terminal sequence distinctly different from that of previously reported mushroom and non-mushroom RNases. The molecular weight of previously reported mushroom RNases ranges from 9 to $42.5 \mathrm{kDa}$. The molecular mass of Hohenbuehelia serotina RNase $(27 \mathrm{kDa})$ lies within this range. It is larger than the mass of RNases isolated from Clitocybe maxima (42), Hypsizigus marmoreus (45), Lyophyllum shimeiji (47), Pleurotus djamor (50), Pleurotus eryngii (51), Pleurotus ostreatus (31), Pleurotus pulmonarius (35), Pleurotus sajor-caju (40), Russula delica (46) and Thelephora ganbajun (43), but smaller than the mass of RNases isolated

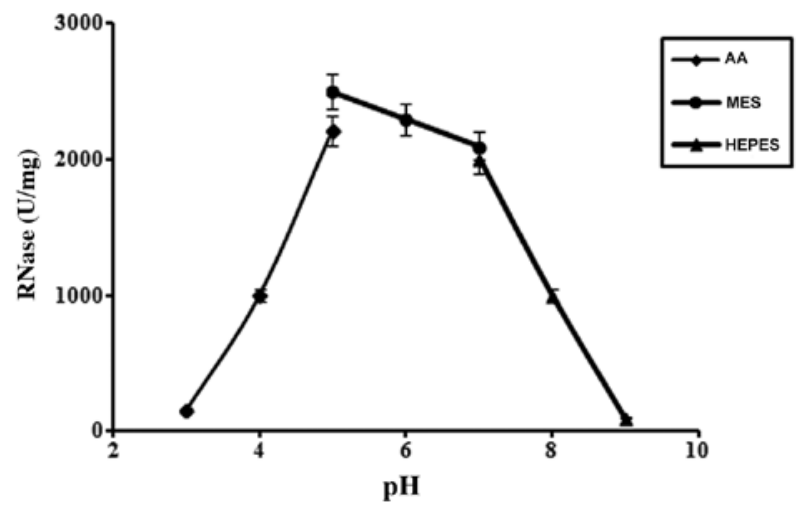

Figure 4. pH dependence of Hohenbuehelia serotina ribonuclease (RNase). Temperature used: $37^{\circ} \mathrm{C}$. Duration of incubation: $15 \mathrm{~min}$. Buffer concentration: $0.1 \mathrm{M}$

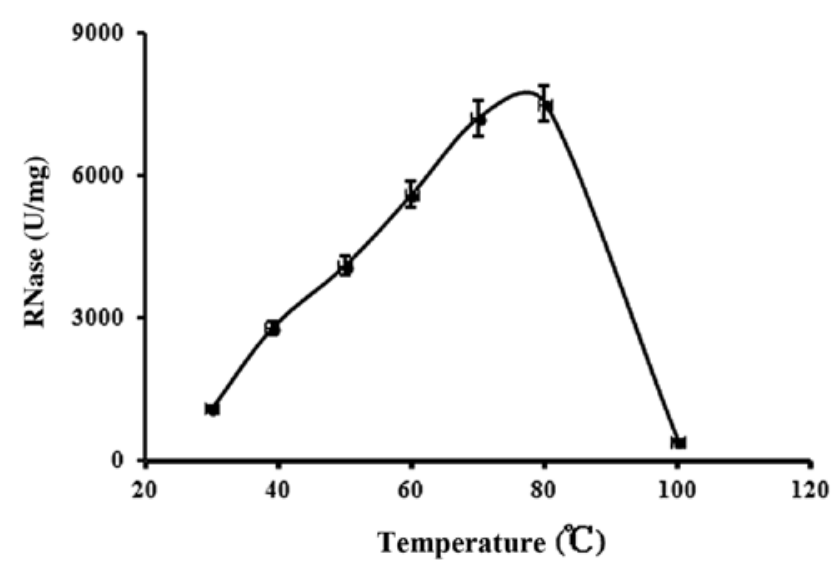

Figure 5. Temperature dependence of Hohenbuehelia serotina ribonuclease (RNase). Buffer used: 0.1 $\mathrm{M} \mathrm{NH}_{4} \mathrm{Ac}$ buffer ( $\mathrm{pH}$ 4.5). Duration of incubation, $15 \mathrm{~min}$.

from Boletus griseus (44), Dictyophora indusiata (52), Ganoderma lucidum (43), Pleurotus tuber-regium (34), Russulus virescens (37) and Volvariella volvacea (33). Its mass is close to that of Dictyophora indusiata RNase (28 kDa) and Russulus virescens RNase (28 kDa). All these RNases are monomeric, and all of them are acid RNases.

RNases isolated from different mushrooms may have different optimum $\mathrm{pH}$ values and temperatures for RNase activity. The optimum $\mathrm{pH}$ of Hohenbuehelia serotina $\mathrm{RNase}$ (pH 5.0) is similar to that of Hypsizigus marmoreus RNase (pH 5.0) [Guan et al (45)] and Russula delica RNase (pH 5.0) [Zhao et al (46)]; however, Hohenbuehelia serotina RNase is much more thermostable. The optimum temperature for the purified Hohenbuehelia serotina RNase was found to be $80^{\circ} \mathrm{C}$, which is the highest optimum temperature for RNases purified from mushrooms.

Some RNases display antiviral activity. Zinc-finger antiviral protein inhibits HIV-1 infection by selectively targeting multiply spliced viral mRNAs for degradation [Zhu et al (53)]. Rana catesbeiana RNase inhibits Japanese encephalitis virus (JEV) replication and enhances apoptosis of JEV-infected BHK-21 cells.

Li et al (54) suggested that the targeted RNase is an alternative anti-hepatitis B virus (HBV) agent. The HIV-1 RT 
inhibitory activity of Hohenbuehelia serotina RNase has been shown to be similar to that of RNases isolated from other mushrooms, such as Lyophyllum shimeiji (47) and Thelephora ganbajun (43). The mechanisms responsible for the inhibitory effects on HIV-1 RT may involve protein-protein interaction, as in the case of the inhibition of HIV-1 RT by the homologous protease (55) and the inhibition of HIV-1 protease by cathelicidin [Wong et al (56)].

Some RNases exert inhibitory effects on tumor cells. The binding of AS RNase and CM-AS RNase to leukaemic cells from patients with chronic lymphatic leukaemia has been demonstrated by indirect immunofluorescence, while no binding to normal leucocytes and leucocytes from patients with other hemoblastoses was observed (24). Bovine seminal RNase (BS-RNase) manifests specific cytotoxic effects on tumor cells, and non-malignant cells are not affected. In view of the finding that success was met only when BS-RNase was applied intratumorally, the properties of BS-RNase were improved by attachment to polylactic acid nanoparticles. The nanoparticle preparation and pure BS-RNase showed no difference when tested against leukemia (MOLT-4) and lymphoma (H9) cell lines sensitive and resistant to cytarabine in vitro. The aspermatogenic and anti-embryonal activities were augmented in the nanoparticle preparation of BS-RNase. It remains to be seen how well BS-RNase attached to polylactic acid nanoparticles performs as an antitumoral agent in vivo [Michaelis et al (57)]. The anticancer effect of the amphibian RNase Onconase as demonstrated experimentally and in clinical trials has been reported (58). Plant RNases have also been shown to exhibit antitumor effects in a number of studies $(18,20,22)$.

Mushroom RNases have been shown to be effective against hepatoma and breast cancer cells (46). Zhao et al (16) noted that Schizophyllum commune RNase had no effect on the proliferation of leukemia and lymphoma cells. Only a few mushroom RNases have been shown to inhibit the growth of leukemia cells $(36,40,59,60)$. We found that the anti-proliferative activities of Hohenbuehelia serotina RNase toward L1210 cells are not as remarkable as those of Pleurotus sajor-caju RNase (40), but more effective than those of Hypsizigus marmoreus RNase (45). To our knowledge, we also demonstrated for the first time that mushroom RNases exhibit anti-proliferative activity toward MBL2 cells.

Some plant RNases have antifungal activity $(27,34,61)$ and have been classified as one family of pathogenesis-related proteins. It is interesting to note that Hohenbuehelia serotina RNase, similar to all previously reported mushroom RNases, is devoid of antifungal activity. However, its antiproliferative activity against cancer cells and its inhibitory activity toward HIV-I RT signify that it is a defense protein. Its RNase activity can be deployed against invaders.

In conlcusion, the RNase isolated from Hohenbuehelia serotina in the present study is a novel RNase, as evidenced by a novel $\mathrm{N}$-terminal sequence and a high optimum $\mathrm{pH}$. It manifests potent anti-proliferative activity toward cancer cells and inhibitory activity toward HIV-1 RT. These biological activities are potentially exploitable. In this regard it is noteworthy that not all previously reported mushroom RNases were assayed for or demonstrate anti-proliferative and HIV-1 RT inhibitory activities.

\section{Acknowledgements}

This study was financially supported by the National Grants of China (no. 2010CB732202) and the Special Fund for Agroscientific Research in the Public Interest (no. 201303080).

\section{References}

1. Vafina MG and Molodtsov NV: Synthesis of some p-nitrophenyl 2-acylamino-2-deoxy-D-glucosides and their hydrolysis with the beta-D-hexosaminidase from Hohenbuehelia serotina. Carbohyd Res 47: 188-194, 1976.

2. Riondel J, Beriel H, Dardas A, Carraz G and Oddoux L: Studies of antitumor activity of the culture filtrate of Hohenbuehelia geogenius (D.C. ex Fr.) Sing (basidiomycete). Arzneimittelforschung 31: 293-299, 1981.

3. Furukawa K, Ying R, Nakajima T and Matsuki T: Hemagglutinins in fungus extracts and their blood group specificity. Exp Clin Immunogenet 12: 223-231, 1995.

4. Shipley SM, Barr AL, Graf SJ, Collins RP, McCloud TG and Newman DJ: Development of a process for the production of the anticancer lead compound pleurotin by fermentation of Hohenbuehelia atrocaerulea. J Ind Microbiol Biotechnol 33: 463-468, 2006.

5. Bala N, Aitken EA, Fechner N, Cusack A and Steadman KJ: Evaluation of antibacterial activity of Australian basidiomycetous macrofungi using a high-throughput 96-well plate assay. Pharm Biol 49: 492-500, 2011.

6. Bala N, Aitken EA, Cusack A and Steadman KJ: Antimicrobial potential of Australian macrofungi extracts against foodborne and other pathogens. Phytother Res 26: 465-469, 2012.

7. Ma Y, Mizuno T and Ito H: Antitumor activity of some polysaccharides isolated from a Chinese mushroom, 'huangmo', the fruiting body of Hohenbuehelia serotina. Agric Biol Chem 55: 2701-2710, 1991.

8. Li X, Wang Z, Wang L, Walid E and Zhang H: Ultrasonic-assisted extraction of polysaccharides from Hohenbuehelia serotina by response surface methodology. Int J Biol Macromol 51: 523-530, 2012.

9. Kikovska E, Wu S, Mao G and Kirsebom LA: Cleavage mediated by the P15 domain of bacterial RNase P RNA. Nucleic Acids Res 40: 2224-2233, 2012.

10. Daoud R, Forget L and Lang BF: Yeast mitochondrial RNase P, RNase $\mathrm{Z}$ and the RNA degradosome are part of a stable supercomplex. Nucleic Acids Res 40: 1728-1736, 2012.

11. Gardner AF, Prangishvili D and Jack WE: Characterization of Sulfolobus islandicus rod-shaped virus $2 \mathrm{gp} 19$, a single-strand specific endonuclease. Extremophiles 15: 619-624, 2011.

12. Hillwig MS, Kanobe C, Thornburg RW and Macintosh GC: Identification of S-RNase and peroxidase in petunia nectar. $\mathrm{J}$ Plant Physiol 168: 734-738, 2011.

13. Lai LB, Chan PP, Cozen AE, Bernick DL, Brown JW, Gopalan V, and Lowe TM: Discovery of a minimal form of RNase P in Pyrobaculum. Proc Natl Acad Sci USA 107: 22493-22498, 2010.

14. Lee OR, Pulla RK, Kim YJ, Balusamy SR and Yang DC: Expression and stress tolerance of PR10 genes from Panax ginseng C. A. Meyer. Mol Biol Rep 39: 2365-2374, 2012.

15. Schroeder J: Purification of antimicrobial peptides from human skin. Methods Mol Biol 618: 15-30, 2010.

16. Zhao YC, Zhang GQ, Ng TB and Wang HX: A novel ribonuclease with potent HIV-1 reverse transcriptase inhibitory activity from cultured mushroom Schizophyllum commune. J Microbiol 49: 803-808, 2011.

17. Teng PK, Anderson NJ, Goldschmidt L, Sawaya MR, Sambashivan S and Eisenberg D: Ribonuclease A suggests how proteins self-chaperone against amyloid fiber formation. Protein Sci 21: 26, 2012.

18. Fang Fei Fang EF, Zhang CZ, Zhang L, Fong WP and Ng TB: In vitro and in vivo anticarcinogenic effects of RNase MC2, a ribonuclease isolated from dietary bitter gourd, toward human liver cancer cells. Int J Biochem Cell Biol 44: 1351-1360, 2012.

19. D'Errico G, Ercole C, Lista M, Pizzo E, Falanga A, Galdiero S, Spadaccini R and Picone D: Enforcing the positive charge of N-termini enhances membrane interaction and antitumor activity of bovine seminal ribonuclease. Biochim Biophys Acta 1808: 3007-3015, 2011. 
20. Fang EF, Zhang CZ, Fong WP and Ng TB: RNase MC2: a new Momordica charantia ribonuclease that induces apoptosis in breast cancer cells associated with activation of MAPKs and induction of caspase pathways. Apoptosis 17: 377-387, 2012.

21. Fang EF and Ng TB: Ribonucleases of different origins with a wide spectrum of medicinal applications. Biochim Biophys Acta 1815: 65-74, 2011.

22. Matousek J and Matousek J: Plant ribonucleases and nucleases as antiproliferative agens targeting human tumors growing in mice. Recent Pat DNA Gene Seq 4: 29-39, 2010.

23. Michaelis M, Matousek J, Vogel JU, Slavik T, Langer K, Cinatl J, Kreuter J, Schwabe D and Cinatl J: Bovine seminal ribonuclease attached to nanoparticles made of polylactic acid kills leukemia and lymphoma cell lines in vitro. Anticancer Drugs 11: 369-376, 2000.

24. Soucek $\mathbf{J}$ and Matousek $\mathrm{J}$ : The binding of bull seminal ribonuclease and its carboxymethylated derivative to human leukaemic cells. Folia Biol (Praha) 25: 142-144, 1979.

25. Lomax JE, Eller $\mathrm{CH}$ and Raines RT: Rational design and evaluation of mammalian ribonuclease cytotoxins. Methods Enzymol: 273-290, 2012.

26. Matousek J, Soucek J, Riha J, Zankel TR, and Benner SA Immunosuppressive activity of angiogenin in comparison with bovine seminal ribonuclease and pancreatic ribonuclease. Comp Biochem Phys B Biochem Mol Biol 112: 235-241, 1995.

27. Gómez-Gómez L, Rubio-Moraga A and Ahrazem O: Molecular cloning and characterisation of a pathogenesis-related protein CsPR10 from Crocus sativus. Plant Biol 13: 297-303, 2011.

28. Choudhary NL, Yadav OP and Lodha ML: Ribonuclease, deoxyribonuclease, and antiviral activity of Escherichia coli-expressed Bougainvillea xbuttiana antiviral protein 1. Biochemistry (Mosc) 73: 273-277, 2008.

29. Kwon YC, Kang JI, Hwang SB and Ahn BY: The ribonuclease L-dependent antiviral roles of human 2',5'-oligoadenylate synthetase family members against hepatitis $\mathrm{C}$ virus. FEBS Lett 587: 156-164, 2013.

30. Nomura H, Inokuchi N, Kobayashi H, Koyama T, Iwama M Ohgi $\mathrm{K}$ and Irie M: Purification and primary structure of a new guanylic acid specific ribonuclease from Pleurotus ostreatus. J Biochem 116: 26-33, 1994.

31. Ye XY and Ng TB: Purification and characterization of a new ribonuclease from fruiting bodies of the oyster mushroom Pleurotus ostreatus. J Pept Sci 9: 120-124, 2003.

32. Watanabe H, Fauzi H, Iwama M, Onda T, Ohgi K and Irie M: Base non-specific acid ribonuclease from Irpex lacteus, primary structure and phylogenetic relationships in RNase T2 family enzyme. Biosci Biotechnol Biochem 59: 2097-2103, 1995.

33. Wang $\mathrm{H}$ and $\mathrm{Ng} \mathrm{TB}$ : Isolation of a new ribonuclease from fresh fruiting bodies of the straw mushroom. Biochem Biophys Res Commun 264: 714-718, 1999.

34. Wang HX and Ng TB: Purification and characterization of a potent homodimeric guanine-specific ribonuclease from fresh mushroom (Pleurotus tuber-regium) sclerotia. Int J Biochem Cell Biol 33: 483-490, 2001.

35. Ye XY and Ng TB: A novel and potent ribonuclease from fruiting bodies of the mushroom Pleurotus pulmonarius. Biochem Biophys Res Commun 293: 857-861, 2002.

36. Ngai P, Wang HX and Ng TB: Purification and characterization of a ubiquitin-like peptide with macrophage stimulating, antiproliferative and ribonuclease activities from the mushroom Agrocybe cylindracea. Peptides 24: 639-645, 2003.

37. Wang $\mathrm{H}$ and $\mathrm{Ng} \mathrm{TB}$ : A ribonuclease with distinctive features from the wild green-headed mushroom Russulus virescens. Biochem Biophys Res Commun 312: 965-968, 2003.

38. Wang HX and Ng TB: Isolation of a ribonuclease from fruiting bodies of the wild mushroom Termitomyces globulus. Peptides 24: 973-977, 2003.

39. Wang HX, Ngai HK and Ng TB: A ubiquitin-like peptide with ribonuclease activity against various polyhomoribonucleotides from the yellow mushroom Cantharellus cibarius. Peptides 24 509-513, 2003.

40. Ngai P and Ng TB: A ribonuclease with antimicrobial, antimitogenic and antiproliferative activities from the edible mushroom Pleurotus sajor-caju. Peptides 25: 11-17, 2004.
41. Wang HX, Ng TB and Chiu SW: A distinctive ribonuclease from fresh fruiting bodies of the medicinal mushroom Ganoderma lucidum. Biochem Bioph Res Commun 314: 519-522, 2004.

42. Wang $\mathrm{H}$ and $\mathrm{Ng} \mathrm{TB}$ : Isolation of a new ribonuclease from fruiting bodies of the silver plate mushroom Clitocybe maxima. Peptides 25: 935-939, 2004.

43. Wang HX and Ng TB: Purification of a novel ribonuclease from dried fruiting bodies of the edible wild mushroom Thelephora ganbajun. Biochem Bioph Res Commun 324: 855-859, 2004.

44. Wang HX and Ng TB: A ribonuclease from the wild mushroom Boletus griseus. Appl Microbiol Biotechnol 72: 912-916, 2006.

45. Guan GP, Wang HX and Ng TB: A novel ribonuclease with antiproliferative activity from fresh fruiting bodies of the edible mushroom Hypsizigus marmoreus. Biochim Biophys Acta 1770: 1593-1597, 2007.

46. Zhao S, Zhao Y, Li S, Zhang G, Wang $\mathrm{H}$ and Ng TB: Zhao S, Zhao YC, Li SH, Zhang GQ, Wang HX and Ng TB: An antiproliferative ribonuclease from fruiting bodies of the wild mushroom Russula delica. J Microbiol Biotechnol 20: 693-699, 2010.

47. Zhang RY, Zhang GQ, Hu DD, Wang HX and Ng TB: A novel ribonuclease with antiproliferative activity from fresh fruiting bodies of the edible mushroom Lyophyllum shimeiji. Biochem Genet 48: 658-668, 2010.

48. Laemmli UK and Favre M: Maturation of the head of bacteriophage T4.I.DNA packaging events. J Mol Biol 80: 575-599, 1973.

49. Collins RA, Ng TB, Fong WP, Wan CC and Yeung HW: A comparison of human immunodeficiency virus type 1 inhibition by partially purified aqueous extracts of Chinese medicinal herbs. Life Sci 60: PL345-351, 1997.

50. Wu X, Zheng SY, Cui L, Wang $\mathrm{H}$ and $\mathrm{Ng}$ TB: Isolation and characterization of a novel ribonuclease from the pink oyster mushroom Pleurotus djamor. J Gen Appl Microbiol 56: 231-239, 2010.

51. Ng TB and Wang HX: A novel ribonuclease from fruiting bodies of the common edible mushroom Pleurotus eryngii. Peptides 25: $1365-1368,2004$

52. Wang HX and Ng TB: A novel ribonuclease from the veiled lady mushroom Dictyophora indusiata. Biochem Cell Biol 81: 373-377, 2003

53. Zhu Y, Chen G, Lv F, Wang X, Ji X, Xu Y, Sun J, Wu L, Zheng YT and Gao G: Zinc-finger antiviral protein inhibits HIV-1 infection by selectively targeting multiply spliced viral mRNAs for degradation. Proc Natl Acad Sci USA 38: 15834-15839, 2011.

54. Li HC, Huang EY, Su PY, Wu SY, Yang CC, Lin YS, Chang WC and Shih C: Nuclear export and import of human hepatitis B virus capsid protein and particles. PLoS Pathog 6: e1001162, 2010.

55. Böttcher M and Grosse F: HIV-1 protease inhibits its homologous reverse transcriptase by protein-protein interaction. Nucleic Acids Res 25: 1709-1714, 1997.

56. Wong JH, Legowska A, Rolka K, Ng TB, Hui M, Cho $\mathrm{CH}$, Lam WW, Au SW, Gu OW and Wan DC: Effects of cathelicidin and its fragments on three key enzymes of HIV-1. Peptides 6: $1117-1122,2011$.

57. Michaelis M, Cinatl J, Cinatl J, Pouckova P, Langer K, Kreuter J and Matousek J: Coupling of the antitumoral enzyme bovine seminal ribonuclease to polyethylene glycol chains increases its systemic efficacy in mice. Anticancer Drugs 13: 149-154, 2002.

58. Nasu M, Carbone M, Gaudino G, Ly BH, Bertino P, Shimizu D, Morris P, Pass HI and Yang H: Ranpirnase interferes with NF- $\mathrm{BB}$ pathway and MMP9 activity, inhibiting malignant mesothelioma cell invasiveness and xenograft growth. Genes Cancer 2: 576-584, 2011.

59. Xia L, Chu KT and Ng TB: A low-molecular mass ribonuclease from the brown oyster mushroom. J Pept Res 66: 1-8, 2005

60. Wu Y, Wang H and Ng T: Purification and characterization of a novel RNase with antiproliferative activity from the mushroom Lactarius flavidulus. J Antibiot (Tokyo) 65: 67-72, 2012.

61. Lam SK and $\mathrm{Ng} \mathrm{TB}$ : Isolation of a novel thermolabile heterodimeric ribonuclease with antifungal and antiproliferative activities from roots of the sanchi ginseng Panax notoginseng. Biochem Biophys Res Commun 285: 419-423, 2001. 